\title{
Detection of selected antibiotic resistance genes using multiplex PCR assay in mastitis pathogens in the Czech Republic
}

\author{
Vladimir Pyatov, Irena Vrtková, Aleš Knoll \\ Mendel University in Brno, Faculty of AgriSciences, Department of Animal Morphology, Physiology and \\ Genetics and CEITEC MENDELU, Brno, Czech Republic
}

Received November 21, 2016

Accepted May 31, 2017

\begin{abstract}
The aim of this research was to develop multiplex polymerase chain reaction assays for the detection of aminoglycoside ( $\operatorname{str} A, \operatorname{str} B)$, sulphonamide (sulI, sulII), tetracycline (tetA, tetB, tetK, tet $M$, tet $O)$, macrolide and lincosamide ( $m s r A$, erm $A, \operatorname{erm} B$, erm $C, m e f A / E)$ genes of resistance in mastitis pathogens (Escherichia coli, Staphylococcus aureus, Streptococcus uberis, Streptococcus agalactiae and Streptococcus dysgalactiae). Applying the established assays, we investigated the distribution of antibiotic resistance genes in the above mentioned species isolated from milk samples in the Czech Republic. Each assay consisted of seven pairs of primers. Six of them amplified fragments of antibiotic resistance genes and one pair a fragment of a species specific gene. Polymerase chain reaction conditions were optimized to amplify seven gene fragments simultaneously in one reaction. In total, 249 isolates were used, among which 111 were positive for E. coli, 52 for $S$. aureus and 86 for Streptococcus spp. The majority $(60.2 \%)$ of bacteria carried at least one antibiotic resistance gene and $44.6 \%$ were multidrug-resistant. The designed multiplex polymerase chain reaction assays may be applied as diagnostic method to replace or complement standard techniques of antibiotic susceptibility testing in the mentioned pathogens.
\end{abstract}

S. uberis, S. aureus, E. coli, S. agalactiae, S. dysgalactiae

Bovine mastitis presents the biggest problem in milk farming (Cressier and B is s onnette 2011). Its worldwide spread endangers food safety, causing enormous economic losses for the dairy industry.

Over 150 different contagious and environmental microorganisms can cause mastitis (Kuang et al. 2009). The most common contagious pathogens are Streptococcus agalactiae, Streptococcus dysgalactiae, Staphylococcus aureus, and Mycoplasma spp. The most common environmental pathogens are Escherichia coli, Klebsiella pneumoniae, Enterobacter aerogenes, Serratia spp., Proteus spp., Pseudomonas spp., and other gramnegative bacteria, coagulase-negative staphylococci, environmental streptococci, yeast or fungi, Prototheca spp., Arcanobacterium pyogenes, and Corynebacterium bovis (Divers and Peek 2008).

Bzdil (2011) reports about the prevalence of mastitis agents in the Czech Republic. Data from 41 regions over a ten year period from 2000 to 2010 were evaluated, showing that the five most frequent pathogens were Streptococcus uberis (22.09\%), Staphylococcus aureus (16.41\%), Escherichia coli (7.01\%), Streptococcus agalactiae $(5.16 \%)$ and Streptococcus dysgalactiae (5.09\%) (Bzdil 2011). In a similar study, which assessed mastitis pathogens in clinically healthy cows, results differ. There, the most prevalent pathogen was Staphylococcus sciuri (14.2\%), followed by Staphylococcus xylosus (10.9\%). Staphylococcus aureus was detected in $9.0 \%$ of the samples, E. coli in $6.6 \%$. So called mastitis streptococci ( $S$. agalactiae, $S$. dysgalactiae, and $S$. uberis) were discovered in $11.7 \%$ of all samples (Cervinkova et al. 2013).

The most common treatment strategy for mastitis is the use of antimicrobial drugs (Pyorala 2009); however, their wide use in veterinary medicine plays a significant role in

Address for correspondence:

Vladimir Pyatov

Department of Animal Morphology, Physiology and Genetics

Faculty of AgriScience, Mendel University in Brno

Phone: +420 545133378

Zemědělská 1, 61300 Brno, Czech Republic 
the increasing resistance to them. As a consequence, the treatment of diseases caused by bacterial pathogens has become very difficult (Schwaiger et al. 2010). For this reason, determining the susceptibility of a microorganism to antibiotics is essential to proper treatment. Testing can demonstrate whether antimicrobial agents are useful against certain causative agents (Willey et al. 2008).

For in vitro testing of antimicrobial susceptibility, methods such as disk diffusion and broth dilution are commonly used (Kalmus et al. 2011). Despite the low cost and easy use, these methods have several disadvantages, such as labour and time consumption and investigator dependence (Driscoll et al. 2013; Hombach et al. 2013).

During the past few years several studies have reported about the application of polymerase chain reaction (PCR) based assays as a diagnostic tool for detecting mastitisassociated pathogens in milk (Shome et al. 2011; Shakuntala et al. 2012). The technique is highly sensitive, enables a high throughput and rapid results (Gao et al. 2011). At the same time, PCR is used to identify genes of resistance. Several multiplex PCR assays for detection of antibiotic resistant genes in E. coli (Sianglum et al. 2009), S. aureus (Strommenger et al. 2003) and streptococci (Malhotra-Kumar et al. 2005) have been developed. Since penicillins and cephalosporins are the most commonly used antibiotics for mastitis treatment (De Briyne et al. 2014), many PCR assays which detect betalactam antibiotic resistance genes have been designed (Pomba et al. 2006). There are further common genes of resistance. For $E$. coli they are: tetA, tetB, strA, strB, sulI, sulII (Srinivasan et al. 2006); for $S$. aureus: ermA, ermB, ermC, msrA, tetM, tetK (Gao et al. 2011; Parvizi et al. 2012); and for streptococci: ermA, ermB, mefA/E, tet $O$, tet $M$ and tet $K$ (Loch et al. 2005; Rato et al. 2013). These genes are responsible for bacteria not being susceptible to aminoglycoside (str $A, \operatorname{str} B)$, sulphonamide (sulI, sulII), tetracycline (tetA, tet $B$, tet $K$, tet $M$, tet $O)$, macrolide and lincosamide ( $m s r A$, ermA, ermB, ermC, mefA/E) antibiotics. These are antibiotics widely used in the treatment of mastitis (Divers and Peek 2008).

Only few PCR assays were applied for the analysis of milk samples and exclusively for detecting genes of resistance in S. aureus (Gao et al. 2011; Parvizi et al. 2012).

The aim of this study was to develop multiplex PCR assays for detecting the most common aminoglycoside, sulphonamide, tetracycline, macrolide and lincosamide genes of resistance in bovine milk samples, originating from the pathogens $S$. uberis, S. aureus, $E$. coli, S. agalactiae and $S$. dysgalactiae. Additionally, the prevalence of these resistances in the Czech Republic was assessed.

\section{Materials and Methods}

A total of 218 cow milk samples were used in this study. The samples were obtained during milking. Desoxyribonucleic acid (DNA) extraction directly from milk samples and bacterial species identification were carried out by using "Thermo Scientific PathoProof" Mastitis Complete-12 assay" (Thermo Fisher Scientific Inc. Waltham, MA USA).

Additionally, 31 bacterial samples isolated from milk with tested antimicrobial susceptibility were included in the assay. For this, colonies of 5 species of interest were obtained from the State Veterinary Institute in Olomouc. Seven of them were $E$. coli, six were $S$. aureus, six were $S$. dysgalactiae, five were $S$. agalactiae, and seven were $S$. uberis. Milk samples had been processed at the State Veterinary Institute in Olomouc with cultivation on blood agar (Trios s.r.o. Prague, Czech Republic) at $37 \pm 1{ }^{\circ} \mathrm{C}$ for $42-48 \mathrm{~h}$. The isolates were tested by the disk diffusion method. The antibiotic panel included streptomycin, tetracycline, neomycin, cefoperazon, novobiocin, clindamycin, cephalothin, amoxycilin/clavulanic acid, cotrimoxazol, oxacilin, colistin, ampicilin and cephalexin.

The DNA extraction from the obtained bacterial colonies was carried out using "DNeasy Blood \& Tissue Kit (50) (QIAGEN ${ }^{\circledR}$ ), which is suitable for such bacterial samples. The DNA concentration and purity were assessed using Nanodrop 2000 (Thermo Fisher Scientific Inc. Waltham, MA USA).

PCR was used for detection of aminoglycoside $(\operatorname{str} A, \operatorname{str} B)$, sulphonamide (sulI, sulII), tetracycline (tet $A$, tet $B$, tet $K$, tet $M$, tet $O)$, macrolide and lincosamide ( $m s r A$, erm $A$, erm $B$, erm $C, m e f A / E)$ resistance genes. To identify the pathogens, the following specific genes were chosen: $m r d B$ for $E$. coli, $r R N A-16 S$ (ribosomal ribonucleic acid) for $S$. agalactiae, rRNA-16S for $S$. dysgalactiae, Cpn60 for $S$. uberis and $r R N A-23 S$ for $S$. aureus. The primers 
Table 1. List of primers.

\begin{tabular}{|c|c|c|c|c|}
\hline Gene & Primer name & Sequence & Product size (bp) & Reference GenBank \\
\hline \multirow[t]{2}{*}{ ermA } & ermA-F & TCAATGGTTGATGTCGTTCA & 165 & $\mathrm{X} 03216$ \\
\hline & ermA-R & AGAAGGGATTTGCGAAAAGA & & \\
\hline \multirow[t]{2}{*}{ ermB } & ermB-F & TTTTTGAAAGCCATGCGTCT & 201 & NC_012926 \\
\hline & ermB-R & CTGTGGTATGGCGGGTAAGT & & \\
\hline \multirow[t]{2}{*}{ ermC } & ermC-F & CAAAACGCTCATTGGCATTA & 257 & NC_024964 \\
\hline & ermC-R & ATCGTCAATTCCTGCATGTT & & \\
\hline \multirow[t]{2}{*}{ strA } & strA-F & CCGTCAATCCCGACTTCTTA & 263 & NC_001740 \\
\hline & strA-R & CCAGTTCTCTTCGGCGTTAG & & \\
\hline \multirow[t]{2}{*}{$\operatorname{str} B$} & strB-F & CGGTCGTGAGAACAATCTGA & 313 & NC_001740 \\
\hline & strB-R & ATGATGCAGATCGCCATGTA & & \\
\hline \multirow[t]{2}{*}{ sulI } & sulI-F & GACGAGATTGTGCGGTTCTT & 350 & $\mathrm{X} 12869$ \\
\hline & sulI-R & AGGGTTTCCGAGAAGGTGAT & & \\
\hline \multirow[t]{2}{*}{ sullI } & SulII-F & CCGTCTCGCTCGACAGTTAT & 399 & M36657 \\
\hline & sulII-R & ATTTGCGCGAAACAGACAG & & \\
\hline \multirow[t]{2}{*}{ tetA } & tetA-F & TGTCCGACAAGTTGCATGAT & 178 & X00006 \\
\hline & tetA-R & CCTTGAACGGCCTCAATTT & & \\
\hline \multirow[t]{2}{*}{ tetB $B$} & tetB-F & CTCCTTGGCTTGGAAAAATG & 229 & NC_018998 \\
\hline & tetB-R & AACCAACCGAACCACTTCAC & & \\
\hline \multirow[t]{2}{*}{ tetO } & tetO-F & TAGCGGAACATTGCATTTGA & 290 & NC_012926 \\
\hline & tetO-R & TTTCTGTAAGTGCCCCAAGC & & \\
\hline \multirow[t]{2}{*}{$\overline{t e t M}$} & tetM-F & AGGGCATCAAGCAACATTTC & 366 & NC_017331 \\
\hline & tetM-R & TCGAGGTCCGTCTGAACTTT & & \\
\hline \multirow[t]{2}{*}{ tetK } & tetK-F & CCCACCAGAAAACAAACCAA & 439 & NC_019148 \\
\hline & tetK-R & СCCTTCACTGATTATGGTGGT & & \\
\hline \multirow[t]{2}{*}{$\overline{m e f A / E}$} & mefE-F & CGTATTGGGTGCTGTGATTG & 248 & U83667 \\
\hline & mefE-R & TATGCACAGGCGTTCCATTA & & \\
\hline \multirow[t]{2}{*}{$m s r A$} & msrA-F & AAGGCTTGTCCGCAATACAC & 320 & X52085 \\
\hline & msrA-R & CCATTACCCCCAATAAGTGC & & \\
\hline \multirow{2}{*}{$\begin{array}{l}23 S r R N A \\
\text { (aur23) }\end{array}$} & aur-F & CTAAGGTGAGCGAGCGAACT & 110 & $\mathrm{X} 68425$ \\
\hline & aur-R & CCTATTCACTGCGGCTCTTC & & \\
\hline \multirow[t]{2}{*}{ cpn60 } & ube-F & ATCAGCCGCAGTTGAAGAAT & 105 & AF485804 \\
\hline & ube-R & TCCCCAACTTTTTCTGAACG & & \\
\hline \multirow{2}{*}{$\begin{array}{l}r R N A-16 S \\
\text { (dys16) }\end{array}$} & dys-F & AAGAATGATGGTGGGAGTGG & 104 & AB002488 \\
\hline & dys-R & CGCTCGGGACCTACGTATTA & & \\
\hline \multirow{2}{*}{$\begin{array}{l}r R N A-16 S \\
\text { (aga16) }\end{array}$} & aga-F & TTACCAGGTCTTGACATCCTTCT & 116 & DQ232512 \\
\hline & aga- $\mathrm{R}$ & GACTTAACCCAACATCTCACGAC & & \\
\hline \multirow[t]{2}{*}{$m r d B$} & col-F & GTCCATCTCGATCCCACAAT & 113 & NC_000913 \\
\hline & col-R & CCGATTTTACGCTCCATCAT & & \\
\hline
\end{tabular}


(Table 1) were designed using Primer3 software and checked for selfdimers, dimers and hairpin structures. The PCR mixture (total volume $10 \mu \mathrm{l}$ ) consisted of $5 \mu \mathrm{l}$ of PPP Master Mix (Top-Bio, Prague, Czech Republic), $1.4 \mu \mathrm{l}$ of primer mix $(0.1 \mu \mathrm{l}$ of each primer [10 pmol], see Table 2$), 3.1 \mu \mathrm{l}$ of PCR water and $0.5 \mu 1$ of the template DNA $(20 \mathrm{ng} / \mu \mathrm{l})$.

PCR was performed under the following conditions: initial denaturation at $95{ }^{\circ} \mathrm{C}$ for $1 \mathrm{~min}, 35$ cycles of denaturation at $95{ }^{\circ} \mathrm{C}$ for $30 \mathrm{~s}$, primer annealing at $60{ }^{\circ} \mathrm{C}$ for $30 \mathrm{~s}$ and elongation at $72{ }^{\circ} \mathrm{C}$ for $30 \mathrm{~s}$, and final elongation at $72{ }^{\circ} \mathrm{C}$ for $7 \mathrm{~min}$. Reaction products were detected using a $2 \%$ agarose gel with ethidium bromide.

All PCR fragments had the correct size. The primers were validated using DNA from genotypically defined isolates which were obtained from the Veterinary Research Institute (Brno, Czech Republic). The isolates were also used as positive controls. The products of the PCRs were sequenced and data were compared to corresponding sequences in the GeneBank using the BLAST algorithm available at the National Center for Biotechnology Information website (www.ncbi.nlm.nih.gov).

Table 2. Multiplex polymerase chain reaction assays made according to targeted bacterial species.

\begin{tabular}{|c|c|c|c|c|c|}
\hline Species & $\begin{array}{c}\text { Escherichia } \\
\text { coli }\end{array}$ & $\begin{array}{c}\text { Staphylococcus } \\
\text { aureus }\end{array}$ & $\begin{array}{c}\text { Streptococcus } \\
\text { uberis }\end{array}$ & $\begin{array}{c}\text { Streptococcus } \\
\text { agalactiae }\end{array}$ & $\begin{array}{c}\text { Streptococcus } \\
\text { dysgalactiae }\end{array}$ \\
\hline \multirow{7}{*}{$\begin{array}{l}\text { name of gene } \\
\text { (product } \\
\text { size in bp) }\end{array}$} & sulII (399) & tetK (439) & tetK (439) & tetK (439) & tetK (439) \\
\hline & $\operatorname{sulI}(350)$ & tetM (366) & tetM (366) & tetM (366) & tetM (366) \\
\hline & $\operatorname{str} B(313)$ & $m s r A(320)$ & teto $(290)$ & tetO $(290)$ & tetO $(290)$ \\
\hline & $\operatorname{str} A(263)$ & ermC (257) & $m e f A / E(248)$ & $m e f A / E(248)$ & $m e f A / E(248)$ \\
\hline & tetB (229) & ermB (201) & ermB (201) & ermB (201) & ermB (201) \\
\hline & tetA (178) & ermA (165) & ermA (165) & ermA (165) & ermA (165) \\
\hline & $\operatorname{mrd} B(113)$ & aur23 (110) & cpn60 (105) & aga16 (116) & dys16 (104) \\
\hline
\end{tabular}

\section{Results}

Strains with tested antimicrobial susceptibility

For the 31 isolates obtained from the State Veterinary Institute in Olomouc, results of the antimicrobial susceptibility test and PCR were compared. A good correlation was observed between phenotypical resistance and detected genes. However, four isolates with the detected genes were not resistant to the corresponding antibiotics. Three $E$. coli isolates, one with detected $\operatorname{str} A$ and $\operatorname{str} B$ genes, the second and the third with detected sulII gene, and one $S$. aureus isolate with detected ermB gene did not show resistance to corresponding antibiotics.

Four isolates of $E$. coli were resistant to tetracycline and carried the tetA gene. Four isolates were resistant to sulphonamide, but six carried the sulII gene and two additionally sulI. Five were resistant to streptomycin (aminoglycoside), but six carried both strA and $s t r B$ genes.

Four isolates of $S$. aureus were resistant to tetracycline, all of them carried the tet $M$ gene and one additionally tet $K$. One isolate was resistant to lincosamide and carried the erm $A$ gene. At the same time, an isolate without resistance to lincosamide carried the ermB gene.

Sixteen isolates of streptococci were tetracycline-resistant. Nine of them carried the tet $M$ gene and seven carried tet $O$. Eight isolates were resistant to lincosamide. Two carried the $m e f A / E$ gene and six carried $e r m B$.

\section{Strains without tested antimicrobial susceptibility}

In total, 218 samples which contained species of interest were used. Following numbers of species were identified: $104 \mathrm{E}$. coli, $46 \mathrm{~S}$. aureus, $25 \mathrm{~S}$. agalactiae, $11 \mathrm{~S}$. dysgalactiae, and 32 S. uberis.

The genes most often detected in $E$. coli were $s t r A$ in 41 samples (39.4\%) and $s t r B$ in 52 samples $(50.0 \%)$. This was followed by tetB, which was found in $31(29.8 \%)$ samples. SulI and sulII were detected in $29(27.9 \%)$ and $26(25.0 \%)$ samples, respectively. TetA was 
found least frequently - only in $22(21.2 \%)$ samples. In total, 9 E. coli isolates carried five antibiotic resistance genes, 12 carried four genes, 7 carried three genes, 14 carried two genes and 11 carried one gene, in different combinations. In 8 samples all six antibiotic resistance genes were detected. No resistance genes were identified in $42 \mathrm{E}$. coli isolates.

For $S$. aureus, msrA was detected in $16(34.8 \%)$ samples, ermC in $13(28.3 \%)$, tetM in $12(26.1 \%)$, tetK in $7(15.2 \%)$, ermB in $4(8.7 \%)$ and ermA in $2(4.3 \%)$ samples. In total, only one $S$. aureus isolate carried five genes, 3 carried four genes, 8 carried three genes, 4 carried two genes and 5 carried one gene, in different combinations. No sample had all six genes. No sought genes were found in 25 samples.

Among streptococci, the most common genes were tet $M$ and ermB, which were detected in $32(47.1 \%)$ and $24(35.3 \%)$ samples, respectively. Tet $K$ was found in $16(23.5 \%)$ samples, tet $O$ in $11(16.2 \%), m e f A / E$ in $9(13.2 \%)$ and $e r m A$ in $6(8.8 \%)$. In total, two isolates carried five genes of resistance, five carried four genes, 13 carried three genes, nine carried two genes and 11 carried one gene. No sample contained all six genes. In 28 isolates none of the sought genes was found.

\section{Discussion}

Despite the simplicity of the phenotypical susceptibility testing methods, the necessity to wait for the results for $48 \mathrm{~h}$ or more is a big disadvantage (Martineau et al. 2000). Multiplex PCR assay which simultaneously allows for the detection of several genes in a single reaction, has the advantage of identifying genotypic resistance to several antibiotics more rapidly and reliably (Choi et al. 2003). In this study, five multiplex PCR assays have been developed to test for the presence of S. uberis, S. aureus, E. coli, S. agalactiae and $S$. dysgalactiae (Table 2) and determine their antibiotic resistance by detecting the related resistance genes. The PCR assays allow highly accurate evaluation of antimicrobial resistance of mastitis pathogens and establishment of effective antibiotic therapy for cows with the disease. The assays could also be used for detection of the genes in samples of another origin.

Another aim of the study was to investigate the distribution of genetic resistance genes in the above mentioned species in milk samples in the Czech Republic. In our study, a total of 249 samples were analyzed. Among them 111 were E. coli, 52 S. aureus and 86 Streptococcus spp.

Of the $E$. coli isolates, 43 did not carry any gene of resistance. This contrasts with Srinivasan et al. (2007) who found at least one resistance gene in each investigated sample. On the other hand, their results show that the majority of $E$. coli $(90.7 \%)$ was multidrug resistant. We also detected a multidrug resistance in the majority of samples, but only to $51.4 \%$.

In a considerable number of $E$. coli isolates, strA (42.3\%) and strB $(52.3 \%)$ genes were amplified, which goes against the results of two other studies (Lanz et al. 2003; Srinivasan et al. 2007). SulI and sulII were detected in $27.9 \%$ and $28.8 \%$ of the isolates, respectively. Karczmarczyk et al. (2011) found similar results for the first gene, but the second one was found in $90 \%$ of isolates. Srinivasan et al. (2007) detected the mentioned genes only in $8 \%$ of all isolates. In their study, TetA $(23.4 \%)$ and tetB $(27.9 \%)$ were also detected at higher frequencies than in that of Srinivasan et al. (2007). Karczmarczyk et al. (2011) found tetB at a similar amount of E. coli as we did, but the presence of tetA was twice as high. Skockova et al. (2012) revealed the mentioned tetracycline resistant genes in highly varying amounts over a longer period.

Almost one third of $S$. aureus carried tetM (30.8\%), whereas tet $K$ was detected only in $15.4 \%$. Similar results for tetracycline resistant genes have been shown in other reports (Gao et al. 2011, 2012). However, Kumar et al. (2010) observed a significantly higher prevalence of tet $K$ compared to tet $M$. 
Molecular analysis also revealed a high number of isolates with $m s r A(30.8 \%)$ and ermC $(25.0 \%)$ genes, but quite few with $\operatorname{ermB}(9.6 \%)$ and $\operatorname{erm} A(5.8 \%)$. Gao et al. $(2011,2012)$ show in both their studies similar results concerning erm $C$, while in one study erm $B$ was detected at a low rate, comparably to our results, and in another one $\operatorname{erm} B$ and $\operatorname{erm} A$ were not found at all. Kumar et al. (2010) revealed $m s r A$ in about a quarter of samples, while erm $A$ and erm $C$ could not be detected. In the work of Parvizi et al. (2012) $m s r A$ was found in $40 \%$ of the isolates and three other resistance genes in $20 \%$ each.

In 86 samples of Streptococcus spp., 57 (66.3\%) carried at least one of the selected resistance genes. A study by Ruegg et al. (2015) demonstrated similar numbers, where $52.6 \%$ of samples were positive. Genes responsible for tetracycline resistance were detected in many samples. The gene tet $M$ was present in almost half of the isolates - $41(47.7 \%)$, tet $O$ in $18(20.9 \%)$ and tet $K$ in $16(18.6 \%)$. Similar results were shown for tet $M$, which was also the most frequent resistance gene discovered (Ruegg et al. 2015). This contrasts with the outcome of Rato et al. (2013), who report tet $K$ as the most often detected tetracycline resistant gene. The most common macrolide resistance determinant was ermB $(34.9 \%)$, followed by $m e f A / E(12.8 \%)$, and $\operatorname{erm} A(7.0 \%)$. The same ranking was shown in a report of Malhotra-Kumar et al. (2005). Combining the outcome of all these studies, it can be concluded that the distribution and relative frequency of genes of resistance in the same bacterial species are highly variable in different regions. Therefore, it is essential to test locally for every region for one cannot rely on data obtained from samples elsewhere.

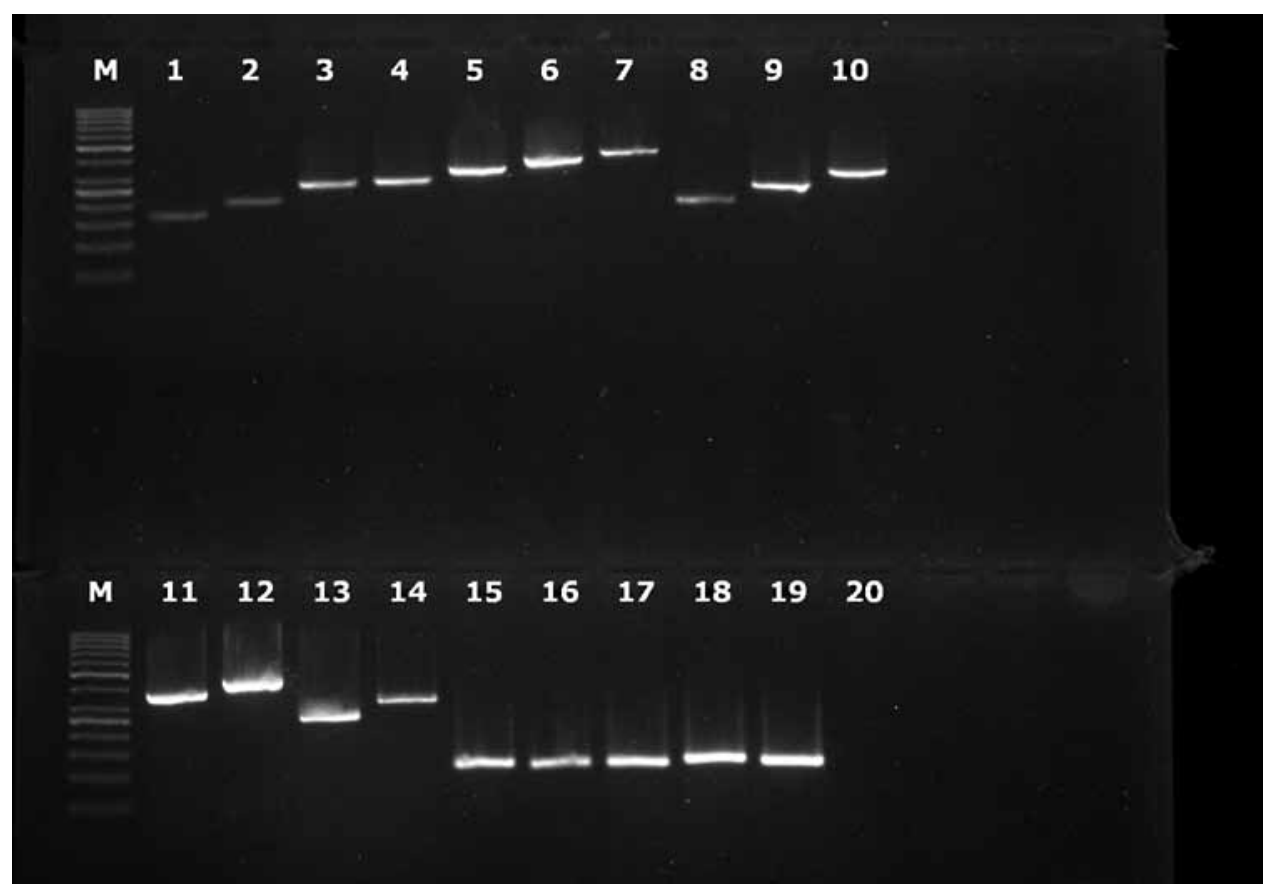

Fig. 1. Gel electrophoresis of multiplex polymerase chain reaction for detection of antibiotic resistance and pathogen specific genes in cow milk samples

Line: $\mathrm{M}$ - 50bp DNA (desoxyribonucleic acid) ladder; 1 - ermA, 2 - ermB, 3 - erm C, 4 - strA, 5 - strB, 6 - sulI, 7 - sulII, 8 - tet A, 9 - tet $B, 10$ - tetO, 11 - tetM, 12 - tet $K, 13$ - mefA/E, 14 - msrA, 15 - rRNA-23S (ribosomal ribonucleic acid) (aur), 16 - cpn60 (ube), 17 - rRNA-16S (dys), $18-r R N A-16 S$ (aga), $19-m r d B$ (col), 20 negative control (water) 
Another thing worth mentioning is the detection of genes of resistance in strains which did not show phenotypical resistance. This phenomenon could be explained by the fact that genes are not the only factors responsible for developing resistance to antibiotics (Cengiz et al. 2015).

The multiplex PCR assays developed in this study showed high sensitivity and specificity for $S$. uberis, $S$. aureus, E. coli, S. agalactiae and S. dysgalactiae (Fig. 1). The method is likely to be helpful for the rapid screening of antibiotic resistance. This research also reported the prevalence of aminoglycoside (strA, strB), sulphonamide (sulI, sulII), tetracycline (tet $A$, tet $B$, tet $K$, tet $M$, tet $O)$, macrolide and lincosamide ( $m s r A$, erm $A$, erm $B$, erm $C, m e f A / E$ ) resistance genes in the bacteria isolated from milk samples of dairy cows in the Czech Republic.

\section{Acknowledgements}

The study was supported by the project of the Ministry of Agriculture of the Czech Republic QJ1210301 and was carried out under the project CEITEC 2020 (LQ1601) with financial support from the Ministry of Education, Youth and Sports of the Czech Republic under the National Sustainability Programme II.

We thank MVDr. Jaroslav Bzdil, PhD for providing the samples with tested antimicrobial resistance and for helpful suggestions.

\section{References}

Bzdil J 2011: Prevalence of selected pathogens of mammary gland in cattle during the years 2000 to 2010. Veterinarstvi 61: 7-11

Cengiz S, Dinc G, Cengiz M 2015: Evaluation of antimicrobial resistance in Staphylococcus spp. isolated from subclinical mastitis in cows. Pak Vet J 35: 334-338

Cervinkova D, Vlkova H, Borodacova I, Makovcova J, Babak V, Lorencova A, Vrtkova I, Marosevic D, Jaglic Z 2013: Prevalence of mastitis pathogens in milk from clinically healthy cows. Vet Med-Czech 58: $567-575$

Choi SM, Kim SH, Kim HJ, Lee DG, Choi JH, Yoo JH, Kang JH, Shin WS, Kang MW 2003: Multiplex PCR for the detection of genes encoding aminoglycoside modifying enzymes and methicillin resistance among Staphylococcus species. J of Korean Med Sci 18: 631-636

Cressier B, Bissonnette N 2011: Assessment of an extraction protocol to detect the major mastitis-causing pathogens in bovine milk. J Dairy Sci 94: 2171-2184

De Briyne N, Atkinson J, Pokludova L, Borriello SP 2014: Antibiotics used most commonly to treat animals in Europe. Vet Rec 175: 13

Divers TJ, Peek SF 2008: Rebhun's diseases of dairy cattle. Saunders, St. Louis, 358 p.

Driscoll AJ, Bhat N, Karron RA, O’Brien KL, Murdoch DR 2012: Disk diffusion bioassays for the detection of antibiotic activity in body fluids: applications for the Pneumonia etiology research for child health project. Clin Infect Dis 54: S159-S164

Gao J, Ferreri M, Liu XQ, Chen LB, Su JL, Han B 2011: Development of multiplex polymerase chain reaction assay for rapid detection of Staphylococcus aureus and selected antibiotic resistance genes in bovine mastitic milk samples. J Vet Diagn Invest 23: 894-901

Gao J, Ferreri M, Yu FQ, Liu XQ, Chen LB, Su JL, Han B 2012: Molecular types and antibiotic resistance of Staphylococcus aureus isolates from bovine mastitis in a single herd in China. Vet J 192: 550-552

Hombach M, Zbinden R and Bottger EC 2013: Standardisation of disk diffusion results for antibiotic susceptibility testing using the Sirscan automated zone reader. BMC Microbiol 13: 225

Kalmus P, Aasmae B, Karssin A, Orro T, Kask K 2011: Udder pathogens and their resistance to antimicrobial agents in dairy cows in Estonia. Acta Vet Scand 53: 4

Karczmarczyk M, Walsh C, Slowey R, Leonard N, Fanning S 2011: Molecular characterization of multidrugresistant Escherichia coli isolates from Irish cattle farms. Appl Environ Microb 77: 7121-7127

Kuang Y, Tani K, Synnott AJ, Ohshima K, Higuchi H, Nagahata H, Tanji Y 2009: Characterization of bacterial population of raw milk from bovine mastitis by culture-independent PCR-DGGE method. Biochem Eng J 45: 76-81

Kumar R, Yadav BR, Singh RS 2010: Genetic determinants of antibiotic resistance in Staphylococcus aureus isolates from milk of mastitis crossbred cattle. Curr Microbiol 60: 379-386

Lanz R, Kuhnert P, Boerlin P 2003: Antimicrobial resistance and resistance gene determinants in clinical Escherichia coli from different animal species in Switzerland. Vet Microbiol 91: 73-84

Malhotra-Kumar S, Lammens C, Piessens J, Goossens H 2005: Multiplex PCR for simultaneous detection of macrolide and tetracycline resistance determinants in streptococci. Antimicrob Agents Ch 49: 4798-4800

Martineau F, Picard FJ, Grenier L, Roy PH, Ouellette M, Bergeron MG, Trial E 2000: Multiplex PCR assays for 
the detection of clinically relevant antibiotic resistance genes in staphylococci isolated from patients infected after cardiac surgery. J Antimicrob Chemoth 46: 527-533

Parvizi M, Doosti A, Dehkordi PG 2012 Detection of antibiotic resistance genes in Staphylococcus aureus strains isolated from cow's milk using multiplex PCR assay. J Pure App Microbiol 6: 1083-1088

Pomba C, Mendonca N, Costa M, Louro D, Baptista B, Ferreira M, Correia JD, Canica M 2006 Improved multiplex PCR method for the rapid detection of beta-lactamase genes in Escherichia coli of animal origin. Diagn Micr Infec Dis 56: 103-106

Pyorala S 2009: Treatment of mastitis during lactation. Irish Vet J 62: 40-44

Rato MG, Bexiga R, Florindo C, Cavaco LM, Vilela CL, Santos-Sanches I 2013: Antimicrobial resistance and molecular epidemiology of streptococci from bovine mastitis. Vet Microbiol 161: 286-294

Ruegg PL, Oliveira L, Jin W, Okwumabua O 2015: Phenotypic antimicrobial susceptibility and occurrence of selected resistance genes in gram-positive mastitis pathogens isolated from Wisconsin dairy cows. J Dairy Sci 98: 4521-4534

Schwaiger K, Holzel C, Bauer J 2010: Resistance gene patterns of tetracycline resistant Escherichia coli of human and porcine origin. Vet Microbiol 142: 329-336

Shakuntala I, Das R, Rajkumari S, Singh P, Dubal ZB, Kumar S 2012 PCR-based detection of Streptococcus agalactiae from milk of bovine subclinical mastitis. Indian J Anim Sci 82: 1009-1011

Shome BR, Das Mitra S, Bhuvana M, Krithiga N, Velu D, Shome R, Isloor S, Barbuddhe SB, Rahman H 2011 Multiplex PCR assay for species identification of bovine mastitis pathogens. J Appl Microbiol 111: 1349-1356

Sianglum W, Kittiniyom K, Srimanote P, Wonglumsom W 2009: Development of multiplex PCR assays for detection of antimicrobial resistance genes in Escherichia coli and enterococci. J Rapid Meth Aut Mic 17: 117-134

Skockova A, Cupakova S, Karpiskova R, Janstova B 2012: Detection of tetracycline resistance genes in Escherichia coli from raw cow's milk. J Microbiol Biotechn and Food Sci 1: 777-784

Srinivasan V, Gillespie BE, Lewis MJ, Nguyen LT, Headrick SI, Schukken YH, Oliver SP 2007: Phenotypic and genotypic antimicrobial resistance patterns of Escherichia coli isolated from dairy cows with mastitis. Vet Microbiol 124: 319-328

Strommenger B, Kettlitz C, Werner G, Witte W 2003: Multiplex PCR assay for simultaneous detection of nine clinically relevant antibiotic resistance genes in Staphylococcus aureus. J Clin Microbiol 41: 4089-4094

Willey JM, Sherwood LM and Woolverton CJ 2008: Prescott, Harley \& Klein's Microbiology. McGraw-Hill, New York, 840 p. 